كاربرد صفحات هدايت جريان در حوضجه رسوبگير براى افزايش راندمان تلهاندازى

\author{
كاظم اسماعيلى"، سهيلا سيفى و هدى سالارى' - إن
}

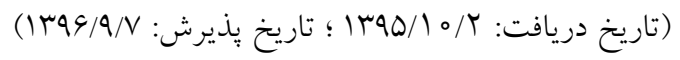

جكيده

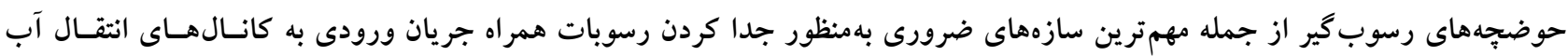

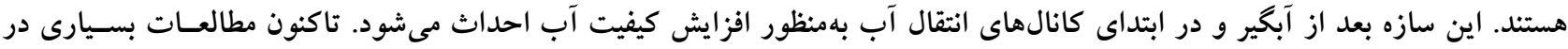

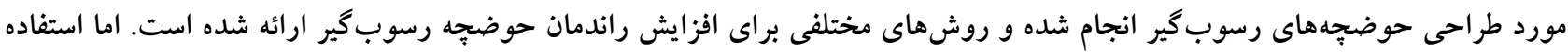

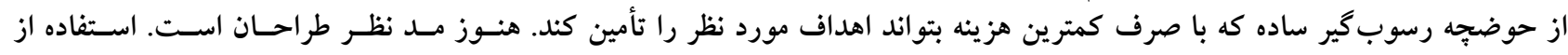

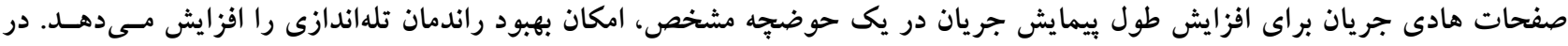

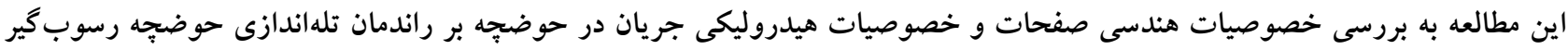

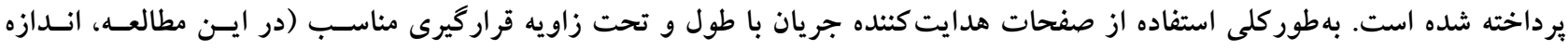

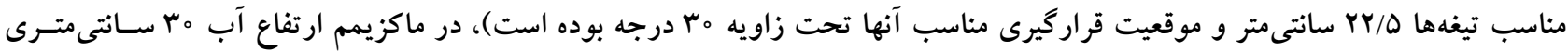

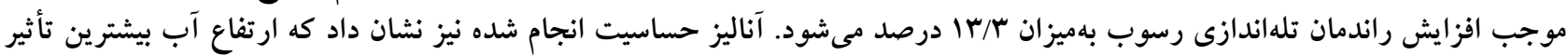

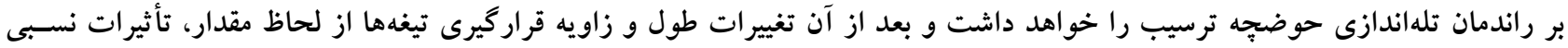

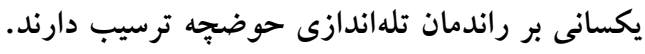

وازههاى كليدى: حوضجه رسوبگير، تيغهاى هدايت كننده جريان، افزايش كيفيت آب 
منابع ارائسه شـــه در ايـن بخـش شـامل دو قسـمت اسـت. قسمت اول شامل مدلهاى رياضى ارائه شــده بـهمنظـور تعيسين

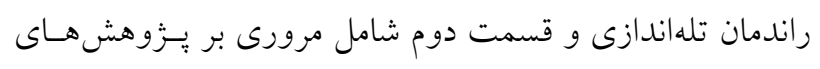

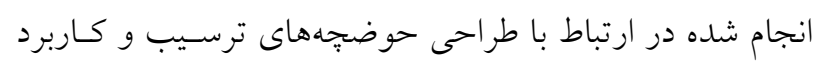

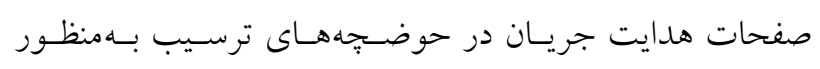
افزايش راندمان است.

مدلهاى رياضى ارائه شده تعيين راندمان حوضجه

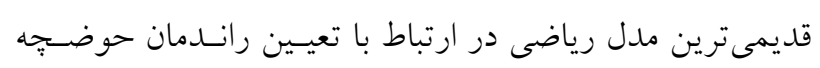

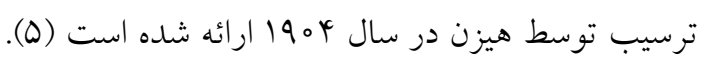

$\eta=1-\left[1+m\left(\frac{w A}{Q}\right)\right]^{-\frac{1}{m}}$

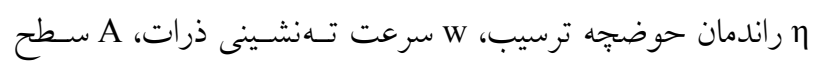

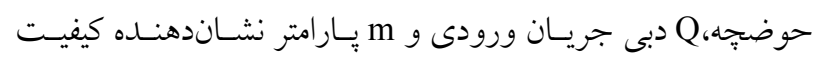

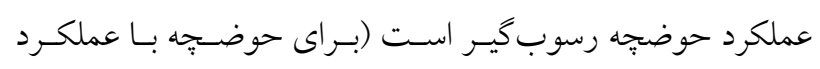

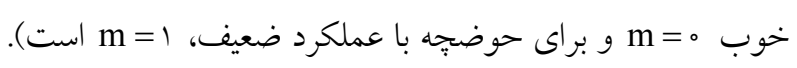

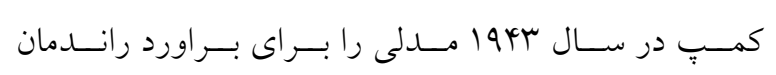

حوضجههاى ترسيب ارائه داد كه شكل كلى آن بهصورت رابل رابطه

$\eta=f\left(\frac{w A}{Q}, \frac{w}{V_{0}}\right)$

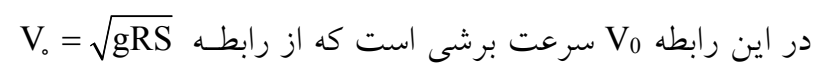

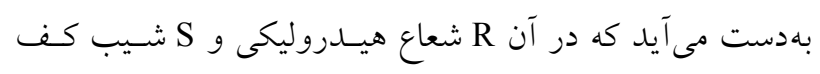

حوضجه است.

كمبٍ در سال 949 1، براساس كارهاى دوبينز مــل ديخــى را با فرضيات زير ارائه داد:

توزيع سرعت در مقطع جريان، سهمى شكل يـا يكنواخـت

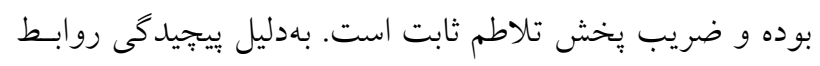

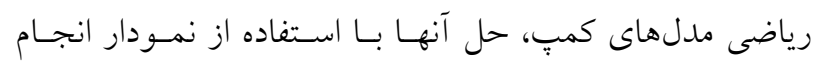

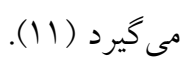

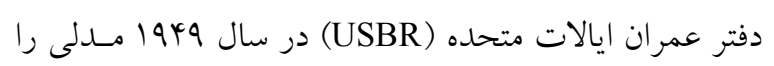

انحراف آب از مسير اصلى آن بـراى مقاصـــ مختلـف از جملـه.

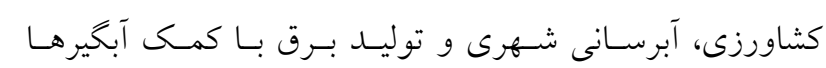

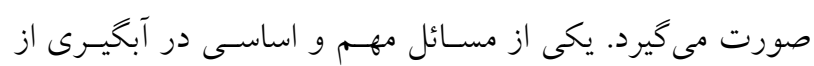

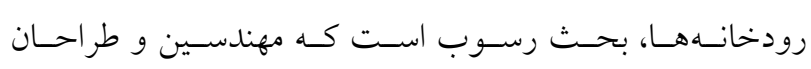
تأسيسات آبى با آن مواجه هستند. در آبخيرى از رودخانهانها بائ رسيد

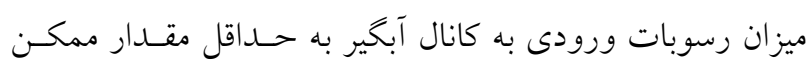

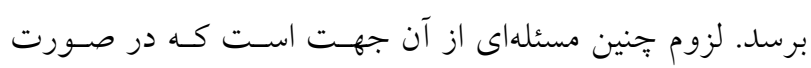

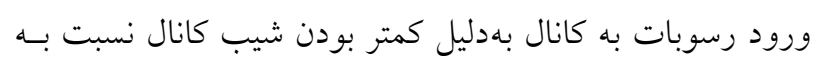

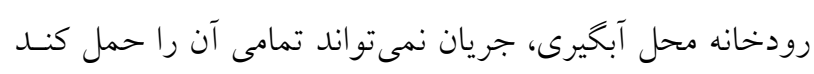

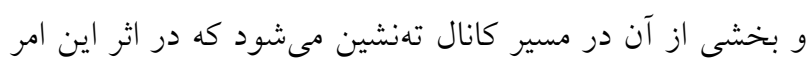

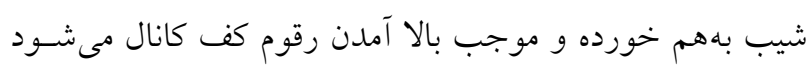

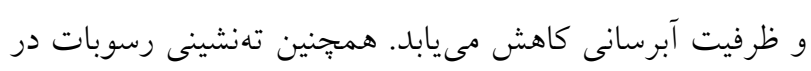

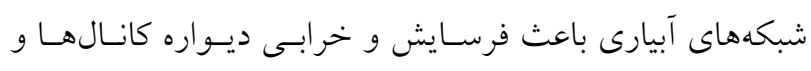

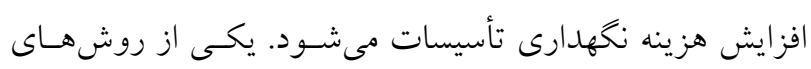

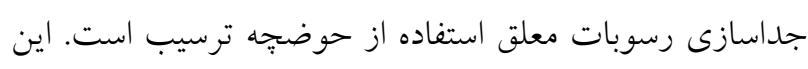
حوضجه داراى مقاطع مستطيل و يا ذوزنقهاى بوده كـه در ابتـدا

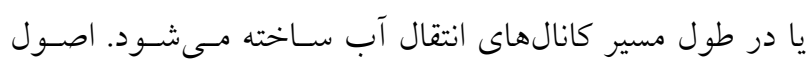

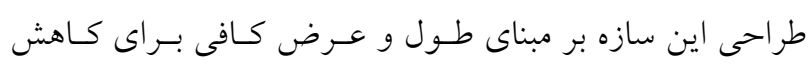

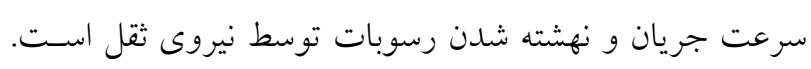

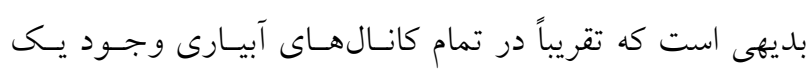

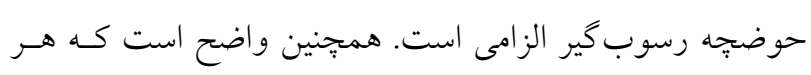

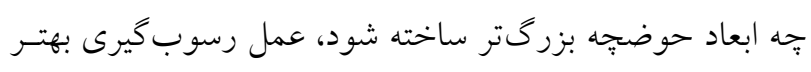

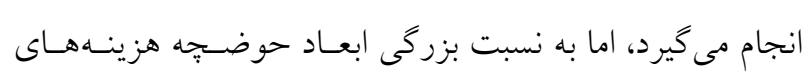

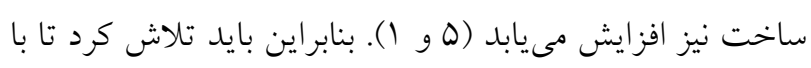

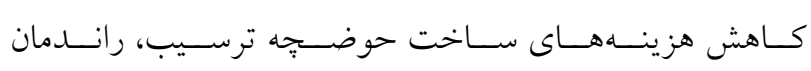

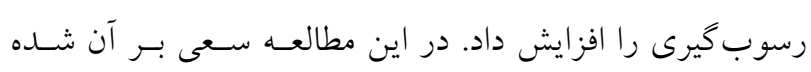

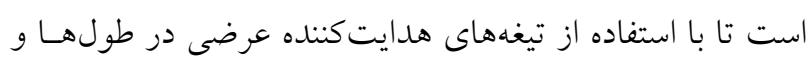
زواياى قرارگيرى متفاوت راندمان حوضجه را را افزايش يابد. در حوضجههاى آبيارى جريان با تبديل بـهــار رفتسه كـاملاً بهصورت دو بعدى در مى آيد و تنوع در شكل ظاهرى آنها كمتر

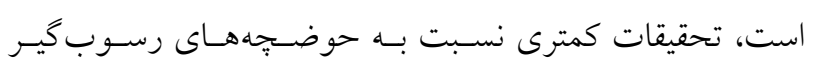



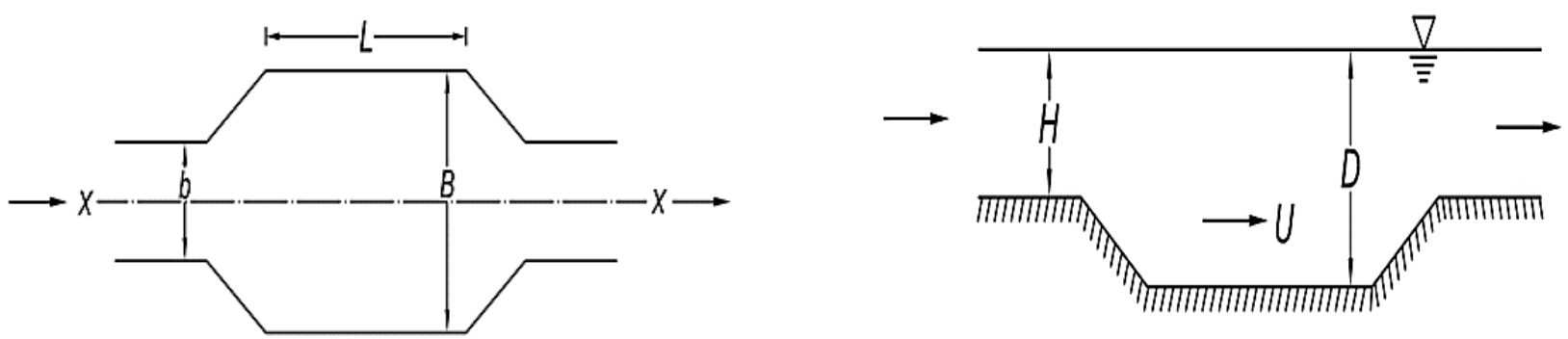

شكل ا. معرفى يارامترهاى استفاده شده در مدل Fasial Ahmad

محاسبه راندمان ارائه دادند (1)).

$\operatorname{Re}=\| 1 / \vee\left(\frac{\omega}{\mathrm{U}}\right)^{\circ / \Lambda}\left(\frac{\mathrm{LB}}{\mathrm{bh}^{\prime}}\right)^{\circ / \pi r}\left(\frac{\mathrm{h}^{\frac{1}{\varphi}}}{\mathrm{n} \sqrt{\mathrm{g}}}\right)^{\circ / 9 \Lambda}$

در اين رابطه bـ bـرض و h' عمـق آب در كانـال نزديـك

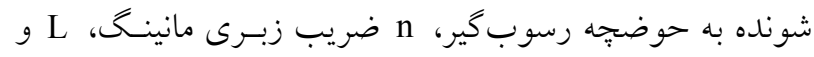
B بهترتيب طول و عرض حوضجه رسوب كير هستند.

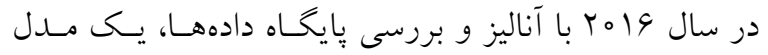
ركرسيونى عمومى براى محاسبه راندمان تلهاندازى رسـوبات در حوضجه رسوب گير ارائه شد. با مقايسه اين مدل و مـدل ارائـه شده توسط راجو و همكاران و بـا بررسى مجــد دادههـا ايسن نتيجه حاصل شدكه مدل ارائه شـده توسـط راجـو و همكـاران تخمين مناسبى از راندمان حوضجه رسوبكير بهدست نمىدهد.

مدل رگرسيونى ارائه شده بهصورت رابطه (V) است: (V) $\eta_{\circ}=r r \xi / r r \Delta\left(\frac{\omega}{\mathrm{U}}\right)^{1 / \Delta \Delta \circ}(\mathrm{Fr})^{r / 11 \wedge}\left(\frac{\mathrm{L}}{\mathrm{H}}\right)^{\circ / \Delta \Delta \wedge}\left(\frac{\mathrm{B}}{\mathrm{b}}\right)^{\circ / \% \vee a}\left(\frac{\mathrm{Un}}{\mathrm{D}^{\frac{r}{r}}}\right)^{-0 / r \Delta v}\left(\frac{\mathrm{d}}{\mathrm{D}}\right)^{-1 / \Delta \circ \wedge}$

در اين رابطه W سرعت سقوط ذره، n ضريب زبرى مانينگ و d d قطر ذره رسوب است. باقى يارامترهـا در شـكل (1) نشـان داده

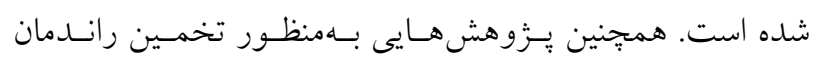
حوضجه ترسيب با استفاده از شبكههاى مصـنوعى انجـام شـده

است (TT).

طراحى حوضجه هاى ترسيب و كـاربرد صـفحات هـدايت جريان در افزايش راندمان اولين مطالعات در مورد طراحسى صـفحات هـدايت جريـان در
براى براورد راندمان حوضجههاى ترسيب در شبكههاى آبيـارى ارائه كردند. شكل رياضى اين مدل بهصورت رابطـهـ (r) اسـت:

$\frac{\mathrm{m}}{\mathrm{m}_{\mathrm{o}}}=\exp \left(-\frac{\mathrm{wL}}{\mathrm{q}}\right)$

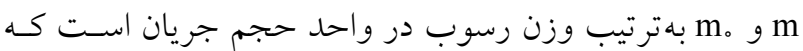
وارد حوضجه شده و از حوضجه خارج مسىشـود و q دبسى در واحد عرض حوضجه ترسيب است. راندمان حوضجه از رابطـه.

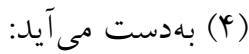

$\eta=1-\frac{m}{m_{0}}=1-\exp \left(-\frac{w L}{q}\right)=1-\exp \left(-\frac{w A}{Q}\right)$

در واقع معادله (Y) همان معادله هيزن بــراى حوضـجههــاى رسوبكير با عملكرد خوب است.

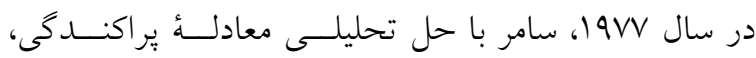
مـلى براى تخمين راندمان حوضجههاى رسوبَ گير ارائه كـرد.

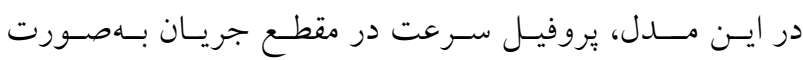
لخـاريتمى در نظـر كرفته شده و ضريب بخش تلاطم نيز متغيـر است. مدل بيشـنهادى بلهصورت رابطه (ه) است: (Y) $\eta=1-\exp \left(-\frac{\lambda U * L}{1 \omega U d}\right)$

در اين رابطـه، U* سـرعت برشسى كـف حوضـهِه، U سـرعت جريـان آب در حوضسجه و $\lambda$ يـارامتر بــون بعـدى اسـت كـه بهمك نسبت راجـو و همكــاران در سـال 1999 بــا اسـتفاده از دادههـاى آزمايشخاهى بهدست آمده از مدل فيزيكى، معادله (9) را بـراى 
سجادى و همكاران به بررسى نقش صفحات كفى عمـودى

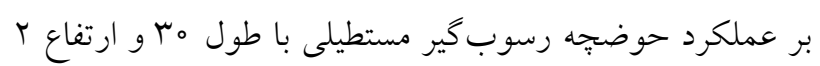

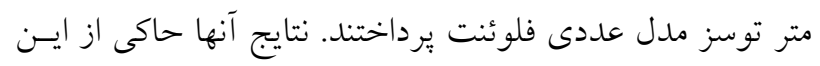

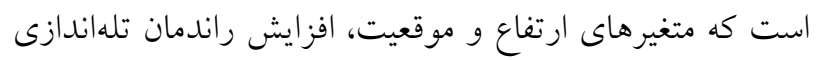

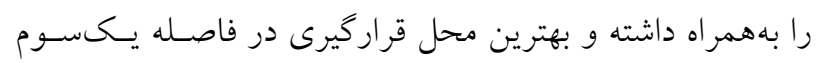

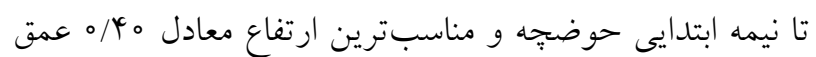

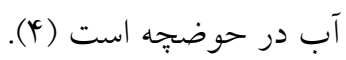

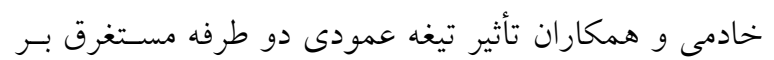

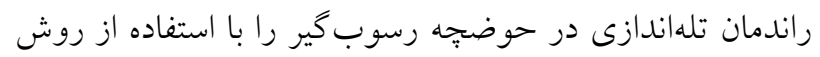

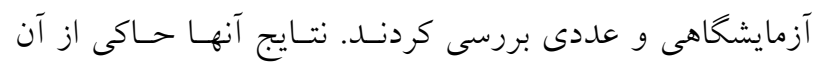

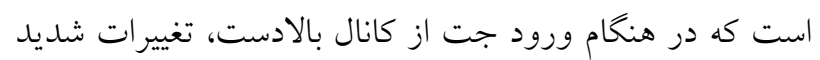

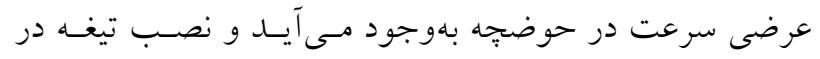

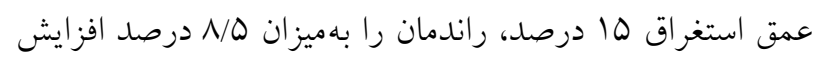

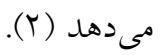
شاهرخى و همكاران به بررسى تأثير تعداد صفحات آرام كنتـده

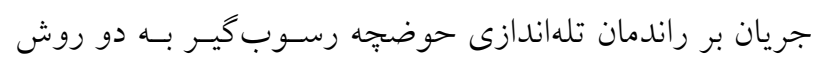

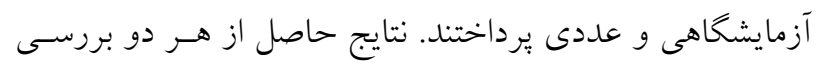

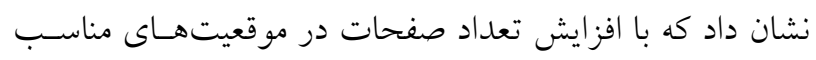

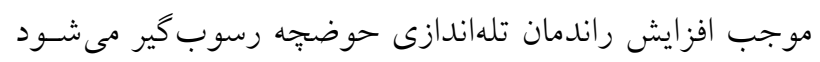

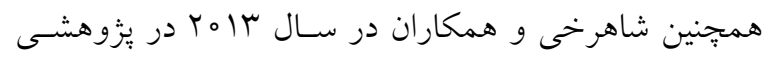

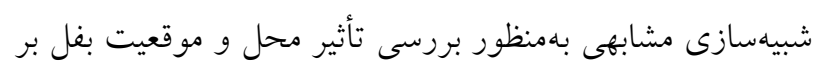

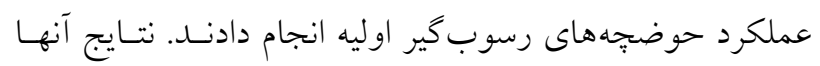

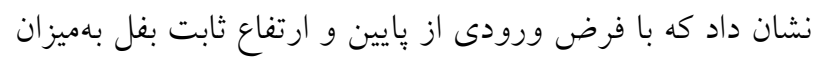
/ /V9

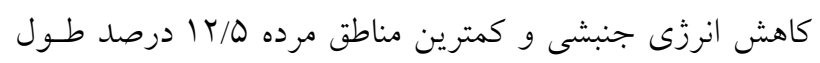

حوضجه بهدست آمد (ro).

حيدرى و همكاران بـه بررسى تـأثير زاويسه صـفحات آرام

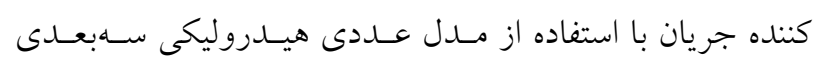

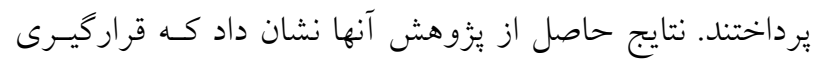

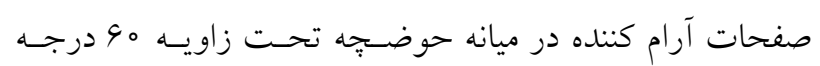

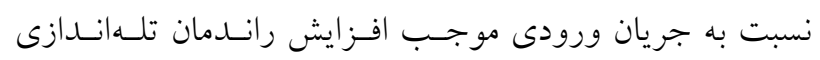

ورودى حوضجه رسوبك كيـر دايسرهاى توسط ويخمسن و مـولر

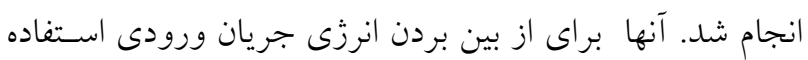
از دو ديواره متخلخل هم مركز را ييشنهاد دادند (Tr).

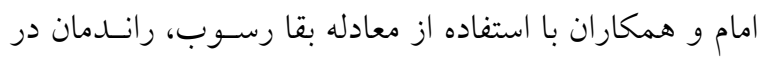

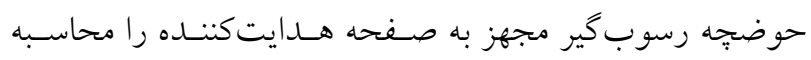
كردند.آنها به اين نتيجه رسيدند كه بهازاى عمق استغراق بهينـه،

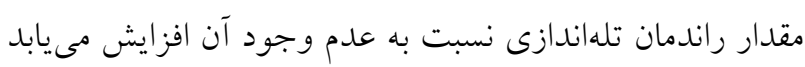

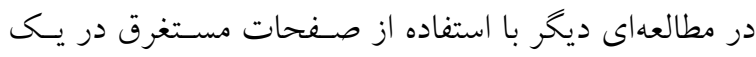

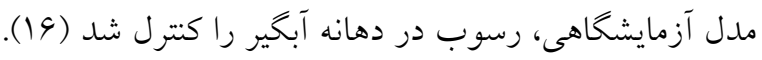

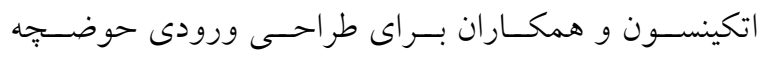

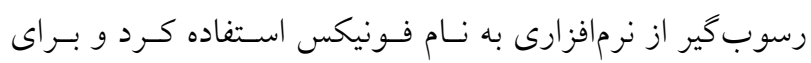
حالتهاى مختلف، ورودى جريان به داخـل حوضسجه را مــل

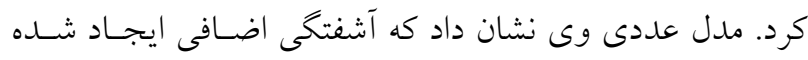

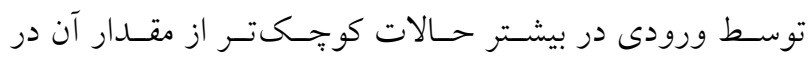

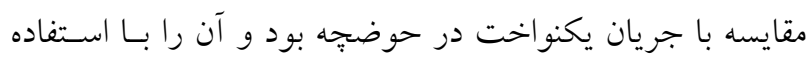

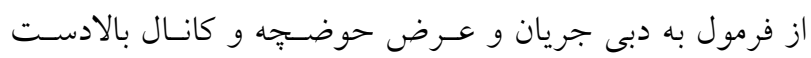

مرتبط ساخت (^) باركدول و همكاران تحقيقـاتى در زمينـه آرايـش صـفحات مستغرق، تركيب صفحات با ديواره جداكنــده و اصـلاح دهانـه آبخير بهصورت آزمايشخاهى (مدل فيزيكى) انجام دادند (9).

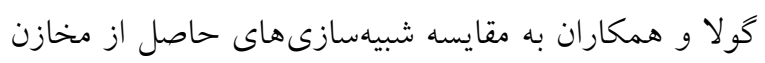

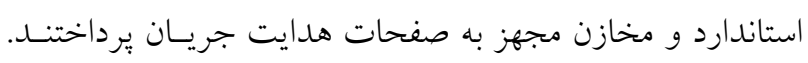

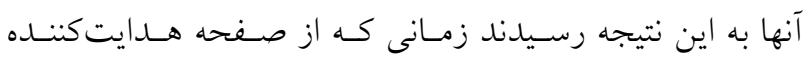

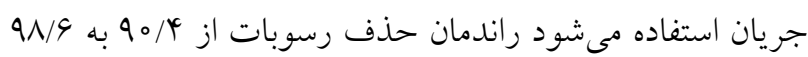
افزايش مى يابد (r) (1).

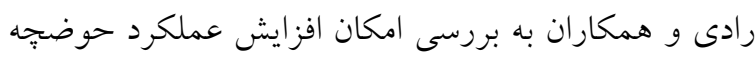

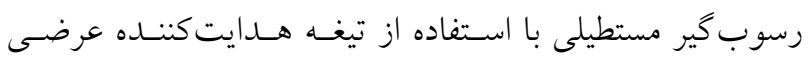

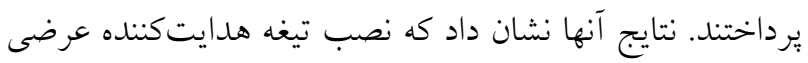

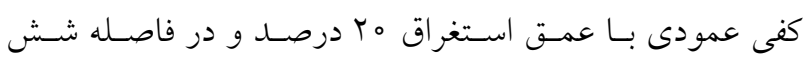
درصدى ابتدايى حوضجه مى تواند موجب افزايش كا درصـدى راندمان حوضجه رسوبَّير با رسوبات ريزدانه شود (9). 


\section{مواد و روش ها - ماد

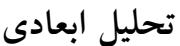

بهمنظور شناخت پِارامترهاى مؤثر بر راندمان تلهاندازى و تعيـين

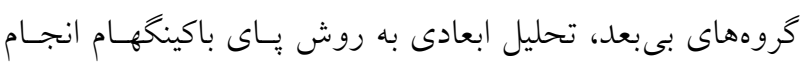

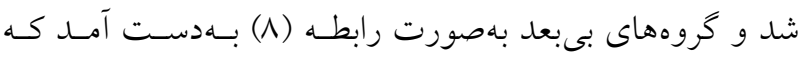

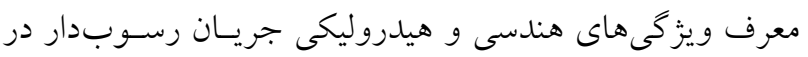
حوضجّه هستند. $\eta=f\left(\frac{B}{L}, \frac{C_{V}}{\rho}, \frac{h}{L}, \frac{1}{L}, \alpha, \frac{\rho_{s}}{\rho}, \frac{d_{s}}{L}, \frac{\rho L \omega_{s}}{\mu}, \frac{\rho L U}{\mu}, \frac{\rho^{r} L^{r} g}{\mu^{r}}\right)$

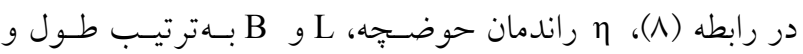

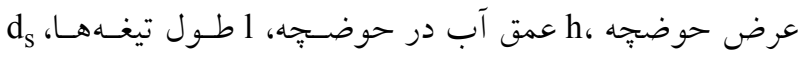
قطر ذرات رسوبى، Ww سرعت سقوط ذره، U سـرعت جريـان

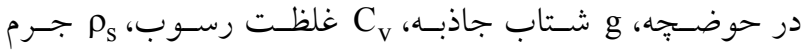

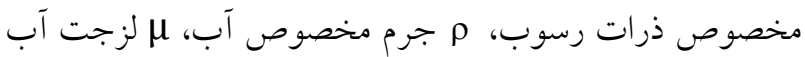
و م زاويه قرارگيرى تيغهها است. يس از حذف پارامترهاى ثابت در رابطه (N) رابطهاى بـدون بعل بهصورت زير تعيين و از بارامترهاى موجود درآن بهمنظـور تحليل نتايج مطالعه حاضر استفاده شد. $\eta=f\left(\frac{h}{L}, \frac{1}{L}, \alpha\right)$

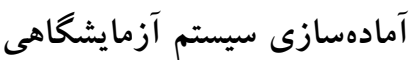
بهمنظور رسيدن به اهداف اين مطالعه، كليه آزمايشها روى يكى

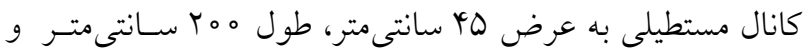

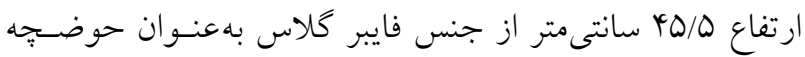

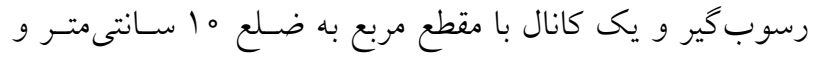

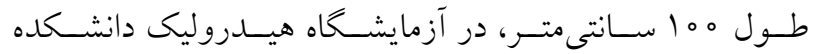

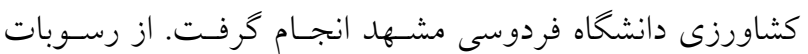

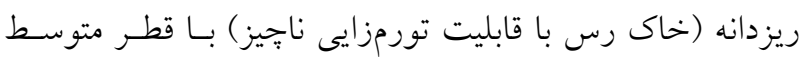

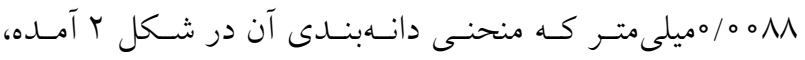

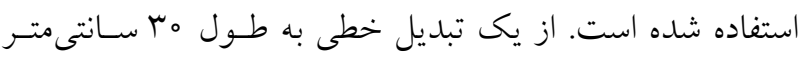

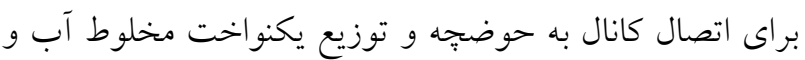

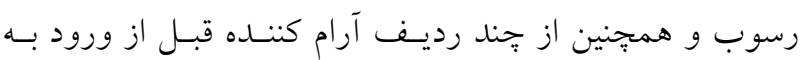

بهميزان V تا \& ا درصد، نسـبت بـه حسالتى كـه حوضـجه فاقـــ صفحه است، مىشود (1) (1).

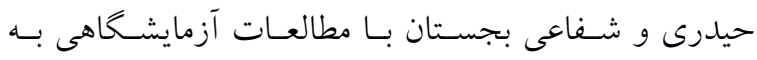

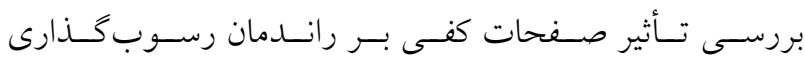

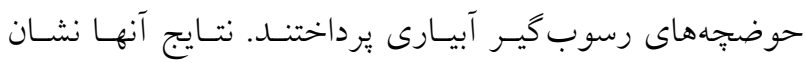
مىدهد كه با كاهش زاويـه صـفحات كفـى از حالـت عمـودى نسبت به جهت جريان، موجب افـزايش رانـدمان مسى لــود كـه بهترين زاويه با بيشترين ميزان افزايش راندمان نسبت به زوايـاى

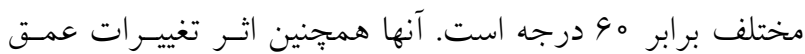
جريان بر راندمان تلهاندازى را بررسى كردنـــ نتسايج نشـان داد جنانجه عمق آب در حوضجه ترسيب كاهش يابد، براى هـر دو

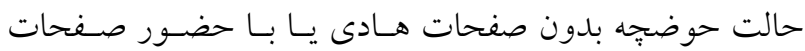

راندمان تلهاندازى تقليل مى يابد (1). در طراحى حوضجههــا بـهدليـل اينكـه طـول حوضسجه رابطه.

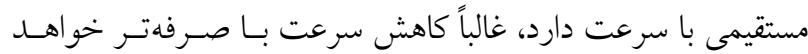

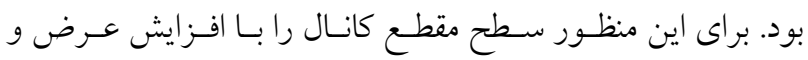

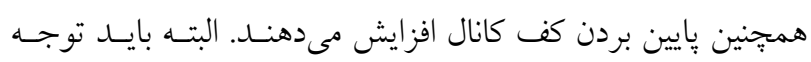

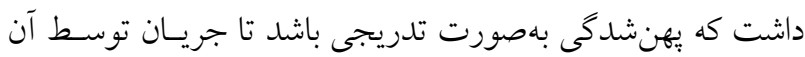

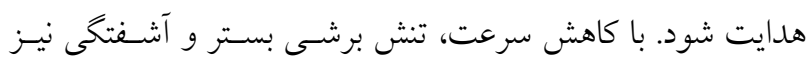

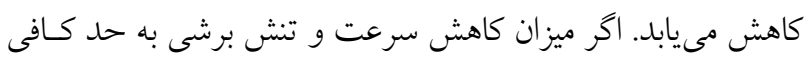

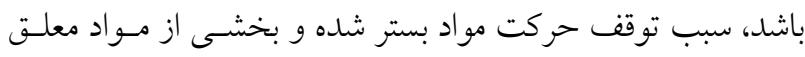

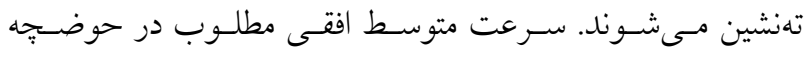

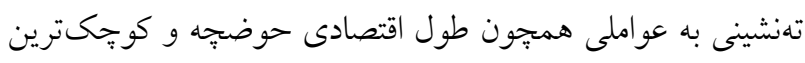
قطر رسوبى كه بايد تهنشين شود، بستخى دارد.

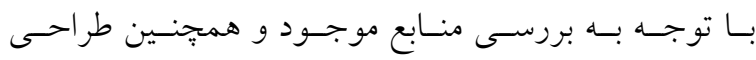

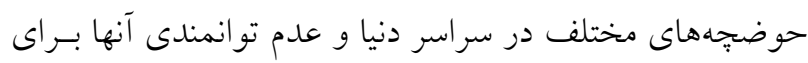

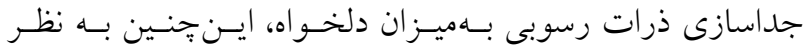
مىرسد كه شرايط براى كار و تحقيق بيشتر در اين زمينه وجـود

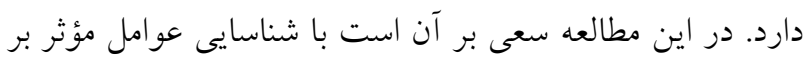

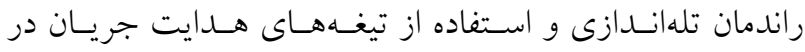
طولها و زواياى قرارگيرى مختلـف، ميـزان رانــدمان حوضـهه ترسيب را به حد مطلوبى افزايش داد. 


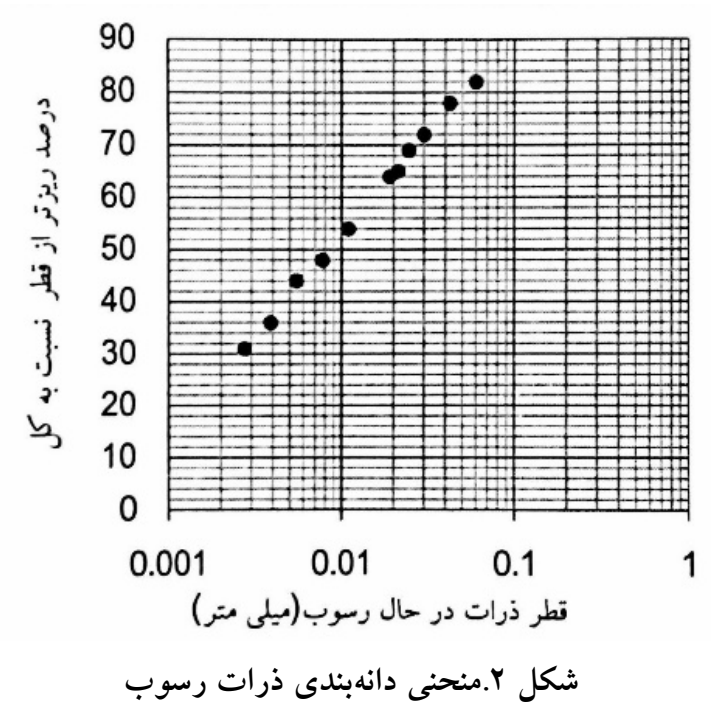

$\eta=\left(\frac{W_{i}-W_{0}}{W_{i}}\right) 1 \cdots$

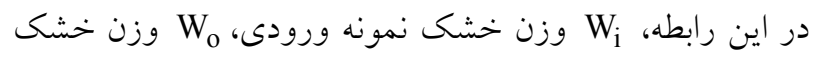

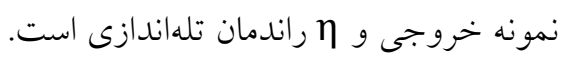

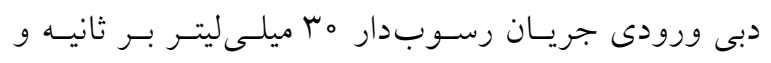

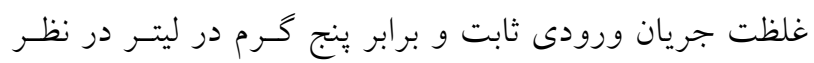
كرفته شد.

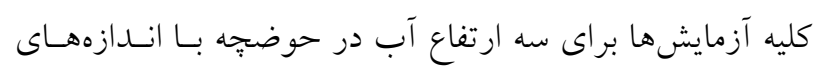

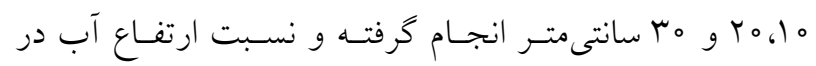

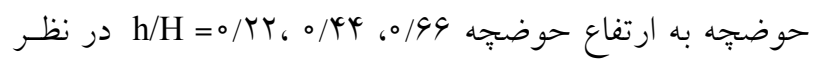
كرفته شد. نسـبت سـرعت سـقوط ذرات بـه سـرعت متوسط جريـان

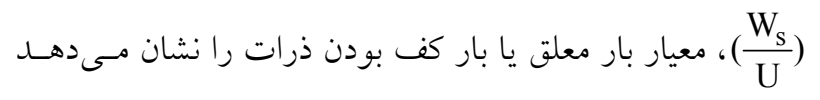
كه براى رسوبات انتخابى و شرايط جريـان در ايـن مطالعـه، در

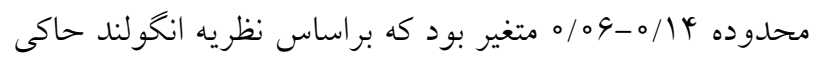
از معلق بودن ذرات در شرايط انتخابى است.

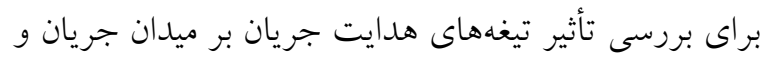

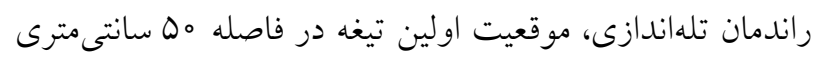

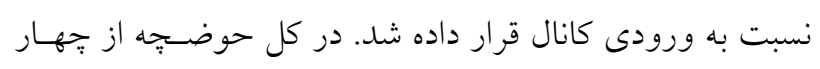

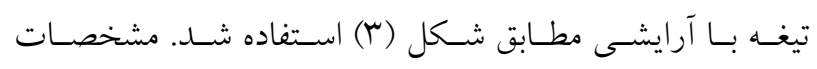
صفحات هدايت جريان در جدول (1) آمدهاست.
حوضجه، براى جلو گيرى از ايجاد تلاطم در هنخام ورود آب از

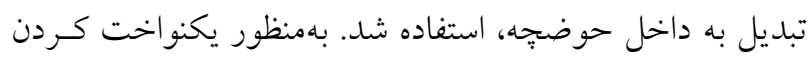

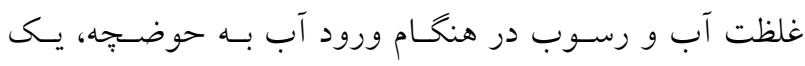

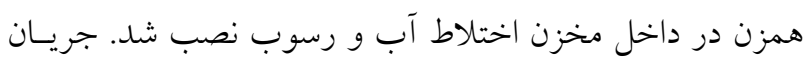

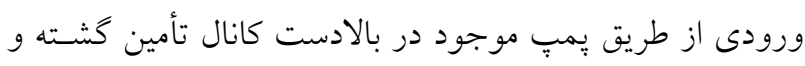

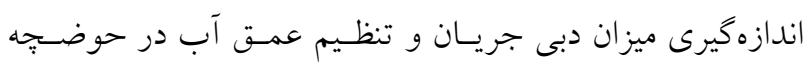

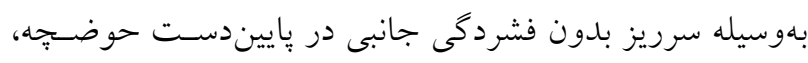

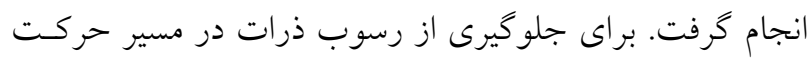
جريان، شيب كانال زياد در نظر كرفته شدر.

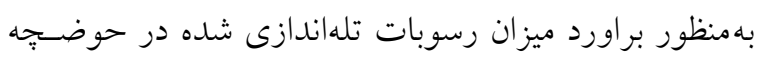

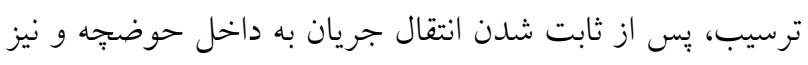

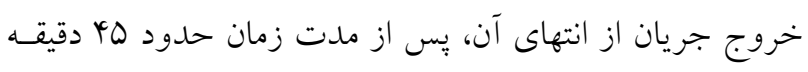

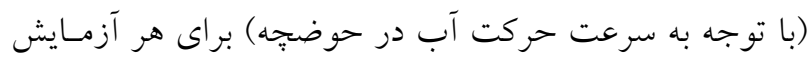

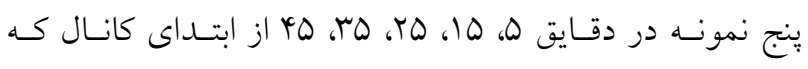

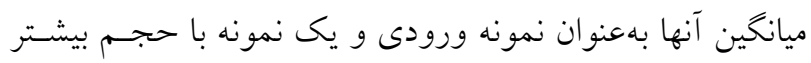

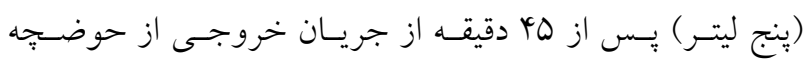

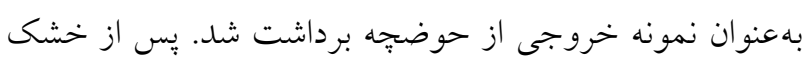

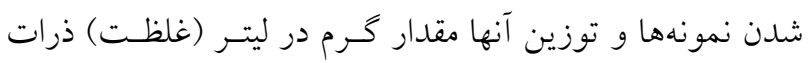
رسوبى در نمونههاى وروديى و خروجى بهدست آمد. بـهمنظـور

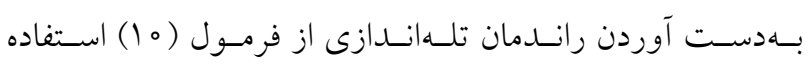
مىشود: - مئ 

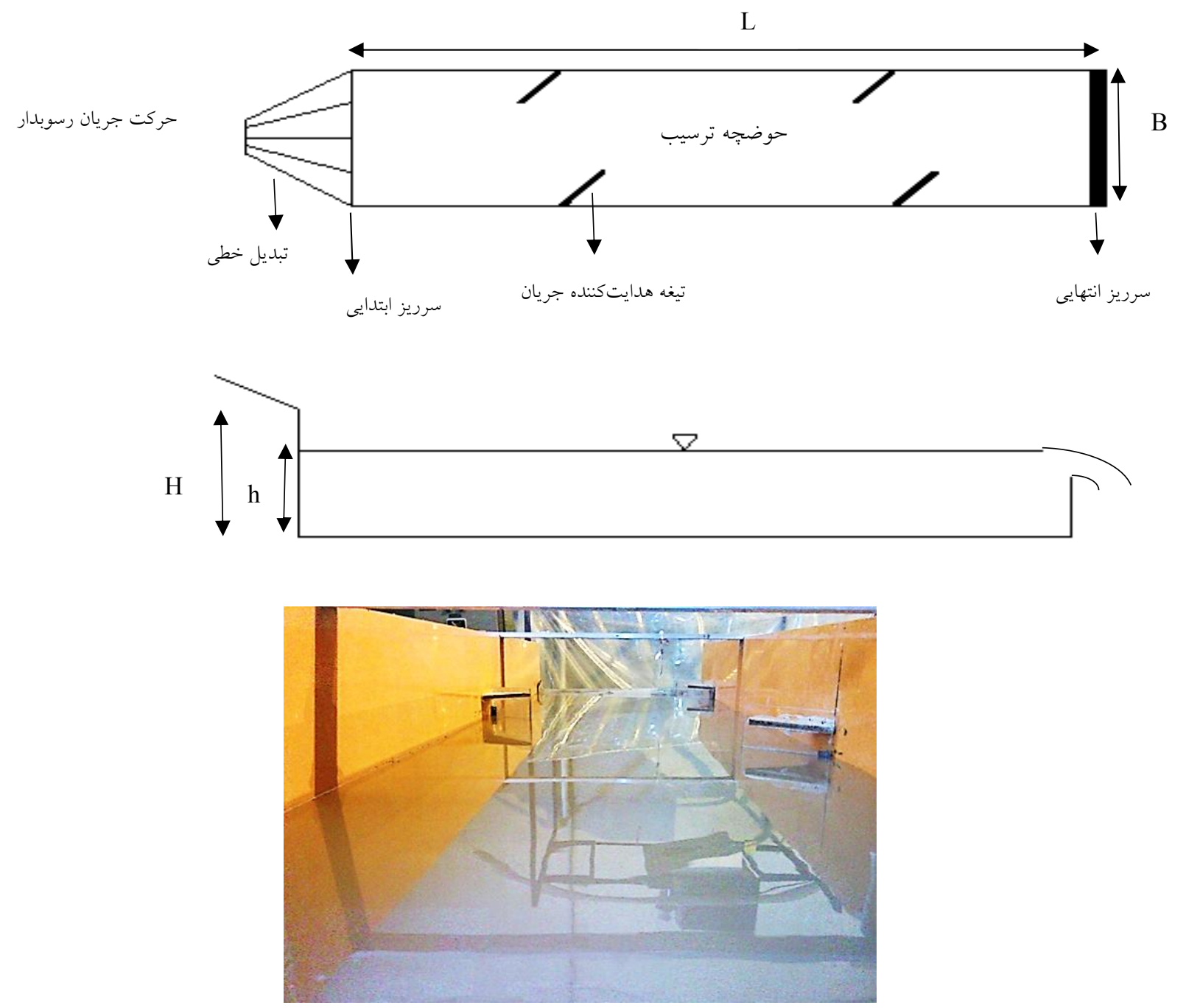

شكل r. نماى بالا، مقطع جانبى و تصويرى از مدل آزمايشعاهى با موقعيت صفحات جدول ا. محدوده يارامترهاى هندسى صفحات هدايت كننده

\begin{tabular}{|c|c|c|c|}
\hline 1 (سانتى متر) & $\alpha$ (درجه) & $1 / \mathrm{B}$ & $\alpha / \alpha \max$ \\
\hline & r。 & & L \\
\hline \multirow[t]{3}{*}{$11 / r T$} & $4 Q$ & $\circ / T \Delta$ & $\circ / 0$ \\
\hline & $9 \circ$ & & 1 \\
\hline & $\mu_{0}$ & & ת \\
\hline \multirow[t]{3}{*}{10} & 40 & س & $\circ / 0$ \\
\hline & 90 & & 1 \\
\hline & $\mu_{0}$ & & سא/. \\
\hline \multirow[t]{2}{*}{$T Y / D$} & 40 & $\circ / 0$ & $\circ / 0$ \\
\hline & 90 & & 1 \\
\hline
\end{tabular}



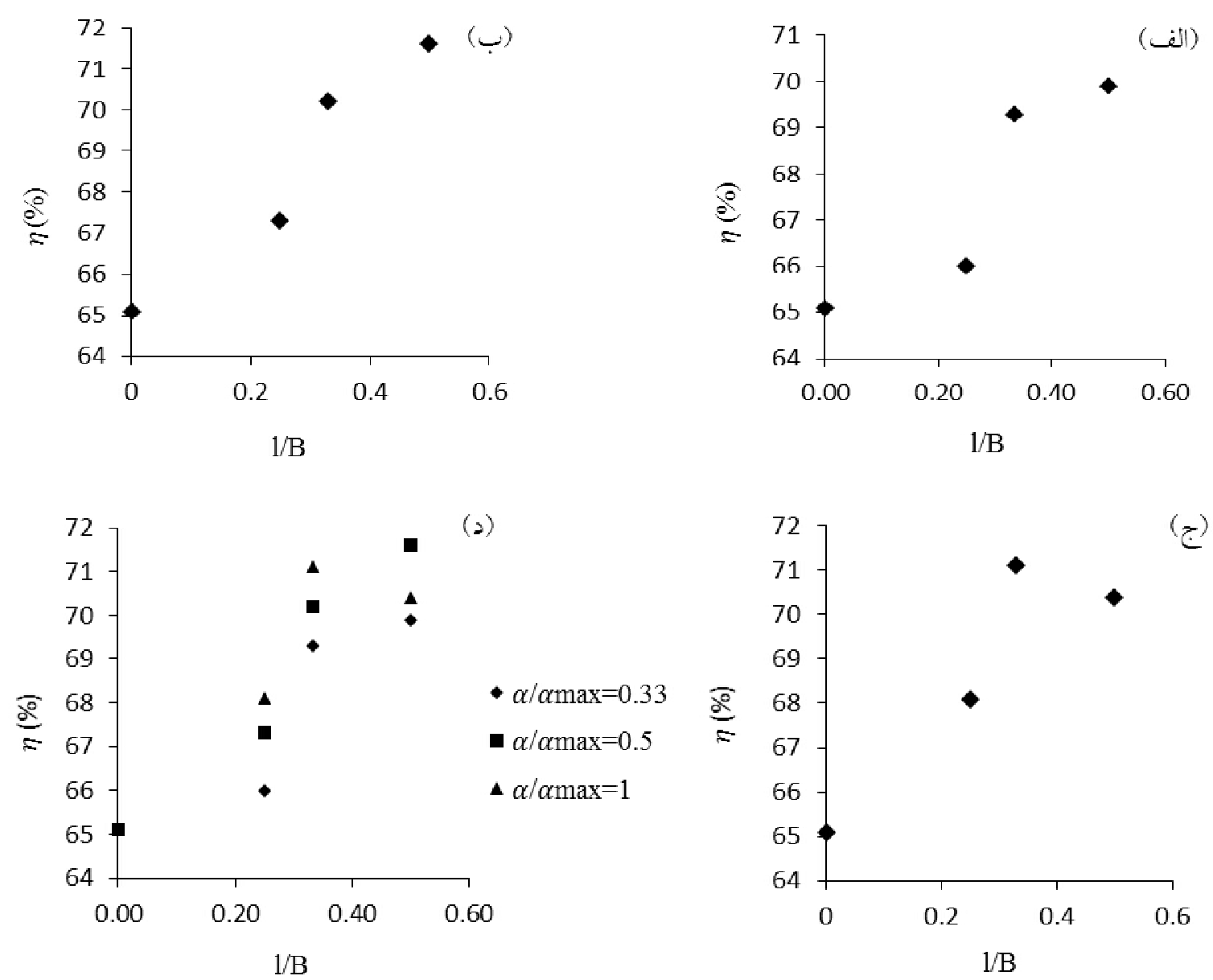

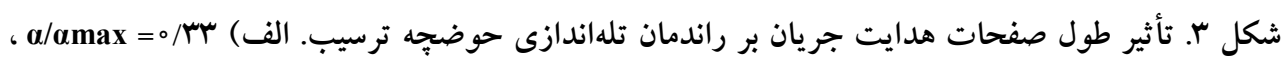

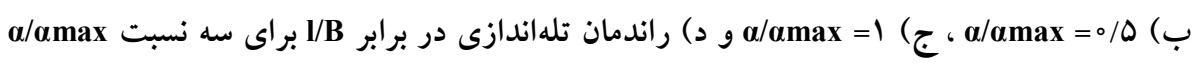

تغييرات راندمان متفاوت از ساير اشكال است و علىرغم انتظار

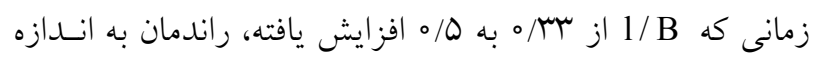

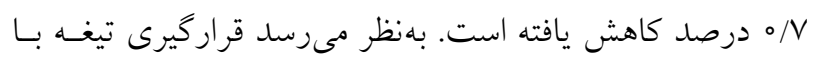

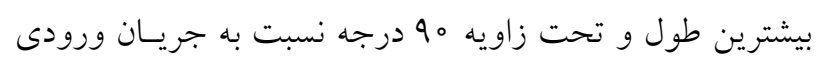

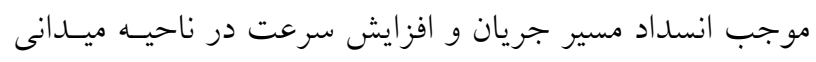

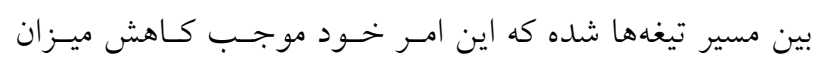

$$
\text { رسوب كذارى مى شود. }
$$

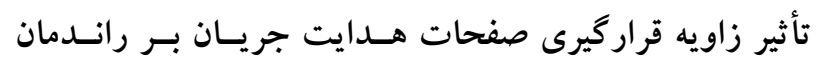
تلهاندازى حوضجه ترسيب بهمنظور بررسى تأثير زاويه قراركيرى صفحات هـدايت جريـان

\section{نتايج و بحث}

تأثير طول صفحات هدايت جريان بـر رانـدمان تلـهانـدازى و بحت حوضجه ترسيب بهمنظور بررسى تأثير طول صفحات هدايت جريان بـر رانـدمان

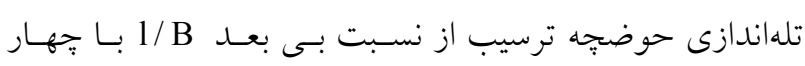

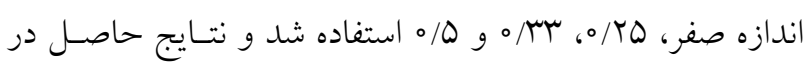

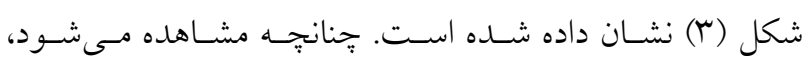

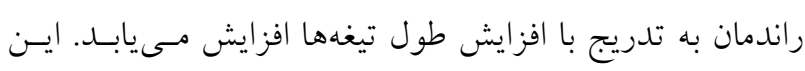
مسئله حاكى از آن است كه با افزايش طول تيغهها ناحيه جريسان

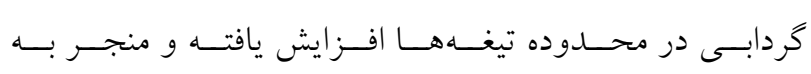

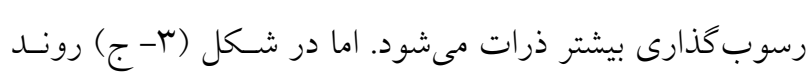



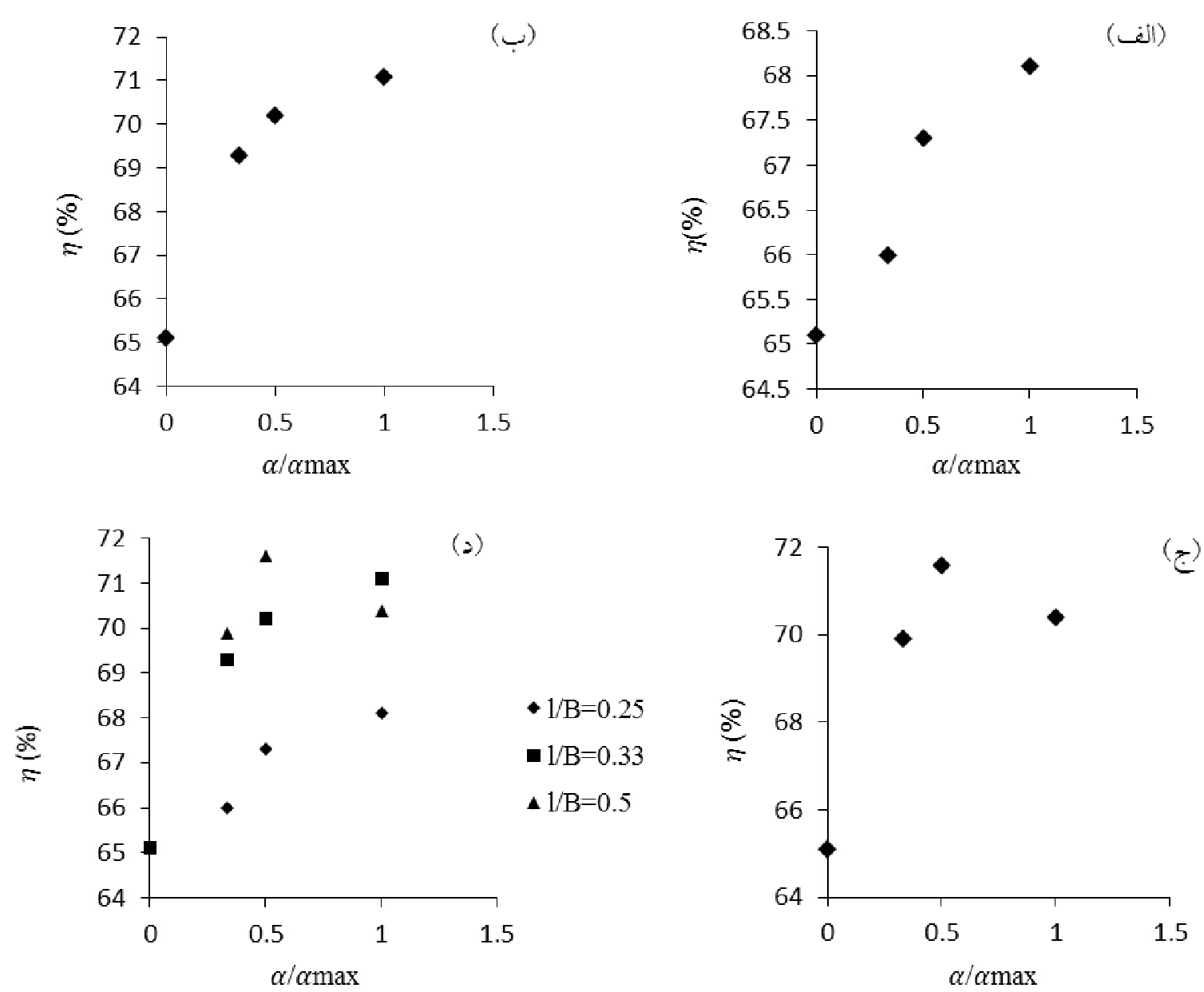

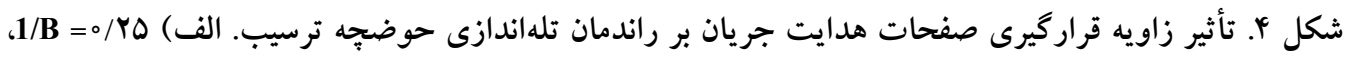

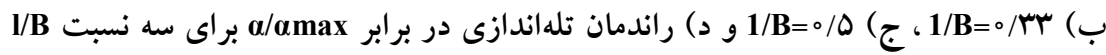

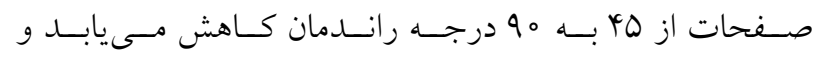

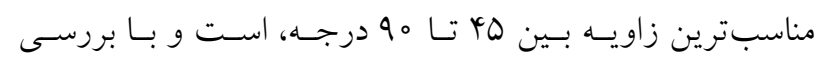

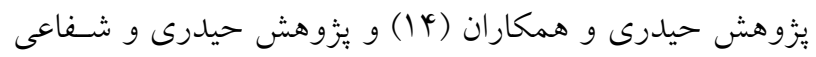
بجستان ( () بهتر بود صـفحات بـا زاويسه مو درجسه نسـبت بـه جريان ورودى نصب مىشــنـد و رانـدمان تلـهانــازى در ايسن. حالت نيز بررسى مى شد. با توجه به شكل (†- د) مىتوان دريافت كه درصد تغييرات

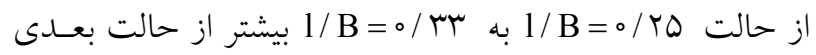

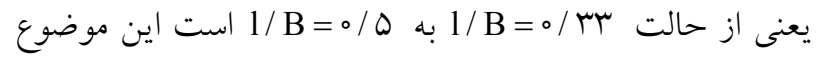
را مىتوان اين جنين توجيه كرد كه اخر جهه افزايش طـول تيغسه، مسير حركت رسوب و در نهايت راندمان را افزايش مىدهد اما
بـر رانــدمان تلـهانــازى حوضـجهه ترسـيب، صـفحات در سـه زاويه ما، هل و هو درجه نسبت به جريان ورودى نصب شـد و

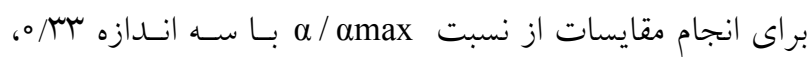
ه/ه و ا استفاده شد و نتايج بـهدست آمـده در ايسن حالـت در شكل (Y) نشان داده شده است. همانطور كه مشـاهده مسى شـود راندمان با افزايش زاويه قرارگيرى صفحات افزايش مىيابد. امـا

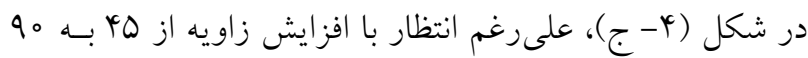

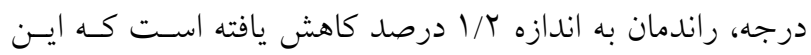
امر بهدليل انسـاد مسـير جريــان و افـزايش سـرعت در ناحيـه

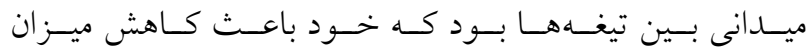
رسوبكذارى مىشود. با توجه به اينكه با تغيير زاويه قرارگيرى 


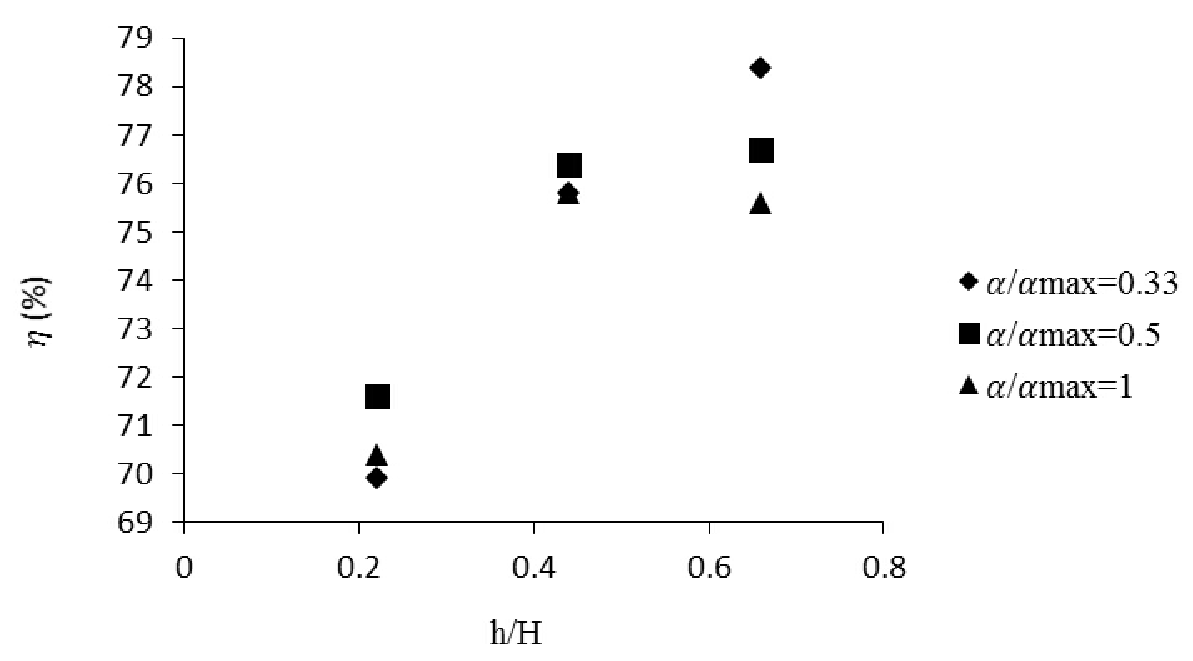

شكل ه. تأثير عمق آب در حوضجه بر راندمان تلهاندازى حوضجه ترسيب براى صفحه با طول Q Y سانتىمتر

ذرات بيشتر شده و راندمان افزايش مى يابد، امـا درصــ فضـاى

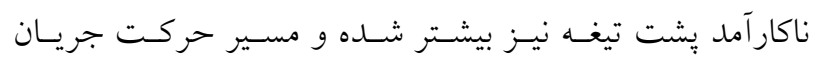

$$
\text { رسوبدار كاهش مى يابد. }
$$

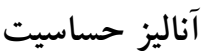

استفاده از آناليز حساسيت جهت تعيين روابـط بـين متغيرهـا بـا

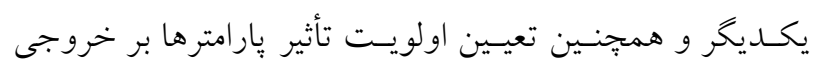

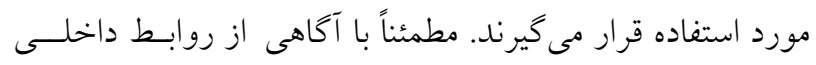

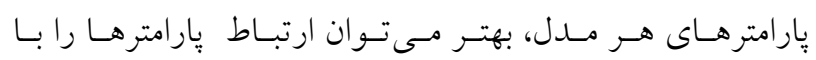

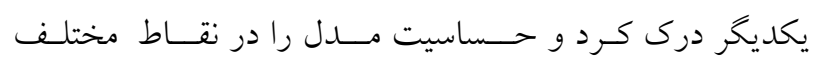

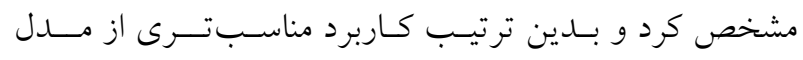
بهمنظور كارايى هرجه بيشتر آن ارائه كرد. نمايه حساسيت زير براى تعيـين ميـزان حساسـيت رانـدمان

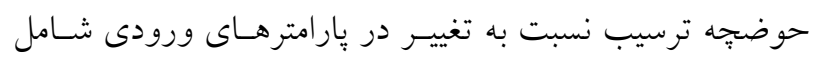

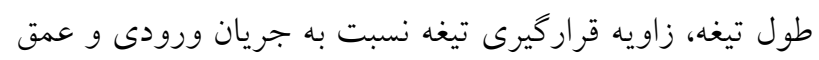
آب در حوضجه مورد استفاده قرار كرفت (9). $\mathrm{S}=\left(\frac{\mathrm{O}_{\mathrm{r}}-\mathrm{O}_{1}}{\mathrm{O}_{\mathrm{avg}}}\right) /\left(\frac{\mathrm{I}_{1}-\mathrm{I}_{\mathrm{r}}}{\mathrm{I}_{\mathrm{avg}}}\right)$ در اين رابطه S نمايه حساسيت، II و I به ترتيب كوجـكتـرين و

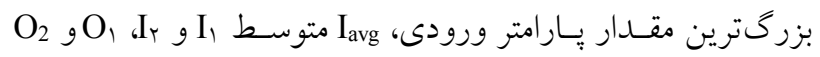

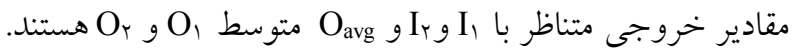

يكى عامل تنگ كننده مقطع جريان است كه افـزايش آن موجـب

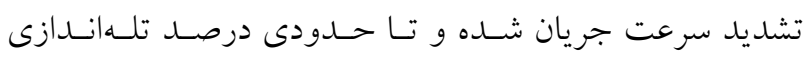

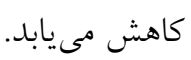

تأثير عمق آب در حوضجه بر راندمان تلهانـدازى حوضـجه ترسيب بهمنظور بررسى تأثير عمق آب بر راندمان تلهانـدازى حوضسجه

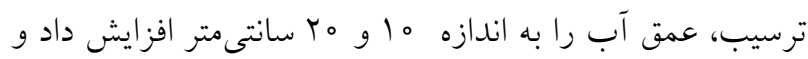

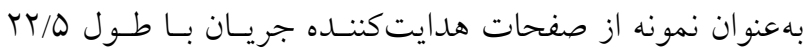
سانتىمتر كه تحـت سـه زاويسه هب، لها و ه9 درجسه نسـبت بـهـ جريان ورودى نصب شده بودند، استفاده شد. نتـايج حاصـل در شكل (ه) نشان داده شده است. همانطور كه مشاهده مى شـود بـا افزايش عمق آب در حوضجه ترسيب، راندمان رسـوبكـذارى

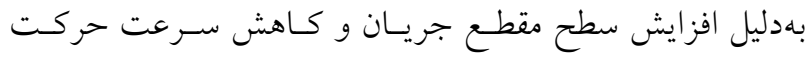
جريان رسوبدار افزايش مىيابد. با توجه بـه شـكل (ه) ميـزان

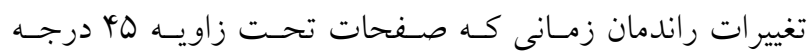

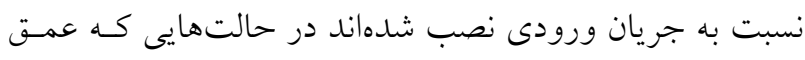

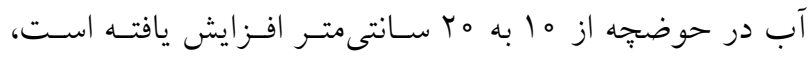

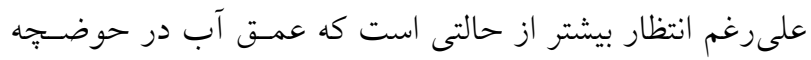

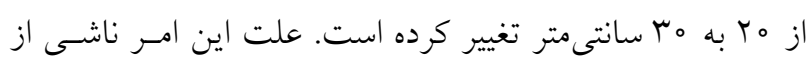

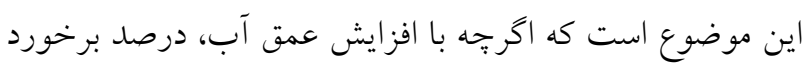




\begin{tabular}{|c|c|c|}
\hline \multicolumn{3}{|c|}{ جدول Y. متغيرهاى انتخابى در بررسى تحليل حساسيت } \\
\hline مقادير پِرامتر خروجى (درصد راندمان) & مقادير يارامترهاى ورودى & يار امترهاى ورودى \\
\hline $9 V / T V$ & $\circ$ & $\alpha_{\min }\left({ }^{\circ}\right)$ \\
\hline$V r / I V$ & 90 & $\alpha_{\max }\left({ }^{\circ}\right)$ \\
\hline$G V / T V$ & $\circ$ & $1_{\min }(\mathrm{cm})$ \\
\hline$V Y / D 1$ & r & $1_{\max }(\mathrm{cm})$ \\
\hline $9 \wedge / 9$ & 10 & $\mathrm{~h}_{\min }(\mathrm{cm})$ \\
\hline$\vee Q / \wedge)$ & $r_{\circ}$ & $\mathrm{h}_{\max }(\mathrm{cm})$ \\
\hline
\end{tabular}

جدول س. مقادير نمايه حساسيت پارامترهاى ورودى

\begin{tabular}{|c|c|c|c|}
\hline ارتفاع آب در حوضجه & زاويه قرارگيرى تيغه نسبت به جريان ورودى & طول تيغه هدايت كننده جريان & 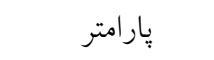 \\
\hline $0 / 09$ & $0 / 04$ & $\circ / \circ \Delta$ & راندمان تلهاندازى \\
\hline
\end{tabular}

بهطوركلى با توجه به نزديك بودن مقـدار نمايـه حساسـيت طول و زاويه قرارگيرى تيغهها، مىتوان نتيجه كرفت كه اين دو عامل تأثيرات بهطور نسبى يكسانى بر راندمان تلهاندازى حوضجه ترسيب دارند. لازم به توضيح است كـه نمايسههـاى حسـساسيت محاســبه شـده، تنها نمايههايى در فضاى رياضى پيارامترها هستند و قطعـاً درك صحيحى از ميزان عدم قطعيت نتايج خروجــى ناشسى از عدم قطعيت موجود در يارامترهاى ورودى را ارائسه نمسىدهنـد. بررسى اين موضوع نياز به تجزيه و تحليل عدم قطعيست و يــا

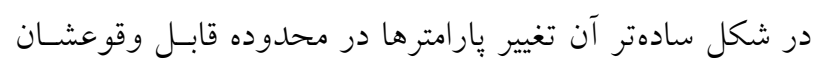
دارد كه خود يزوهش جامع ديخرى را طلب مسىكنـد.

\section{نتيجه گيرى}

در اين مطالعه به بررسى تأثير صفحات هــايت كنــده جريـان و

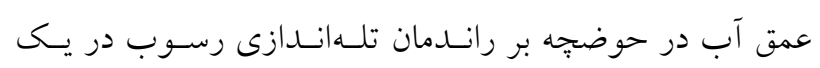
حوضجه رسوب كير مستطيلى با توجـهـ بـهـ نتـايج آزمايشـحاهى يرداخته شد. نتايج نشان داد راندمان تلهاندازى تا حد زيادى بـهـ

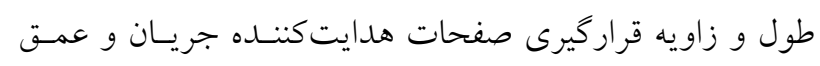

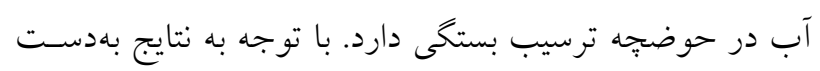

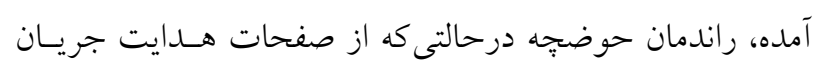

در جدول (r) كوجّكترين و بزرگترين مقدار هـر يـكى از هار امترهاى ورودىى و مقادير پِارامتر خروجى (درصــ رانـدمان) متناسب با آنها آورده شده است.

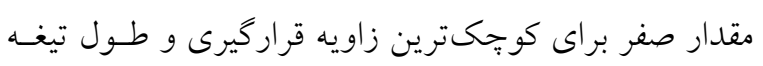
مربوط به حـالتى اسـت كـه حوضسجه ترسـيب فاقـد صـفحات هدايت كننده جريان است. براى بررسى تحليل حساسيت نسبى هر يـك از يارامترهـاى

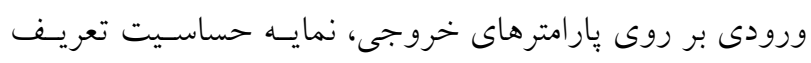

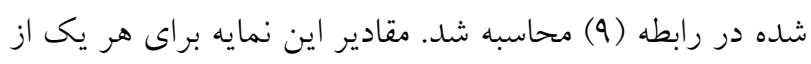
يار امترهاى ورودى در جدول (T) ارائه شده است. مثبت بودن مقادير نمايه حساسيت در جدول (سا) بـه معنسى اين است كه با افزايش مقادير بِارامترهاى ورودى، مقدار پيارامتر

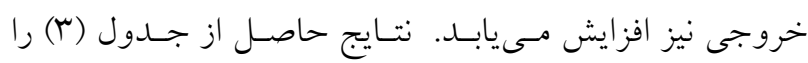
مىتوان به شرح زير كزارش كرد. تغيير در ارتفاع آب در حوضجهه مىتواند بيشترين تأثير رابر روى راندمان حوضجه ترسيب بحًارد. بهغير از ارتفاع آب در حوضجهه، با توجــه بــه مقـدار نمايسه حساسيت، طول تيغههاى هـدايت كنتـده جريـان نسـبت بـه زاويه قراركيرى تيغهها تأثير بيشترى بر راندمان تلـهانـدازى حوضجه ترسيب دارد. 
بدون صفحات راندمان افزايش مي يابد. ماكزيمم راندمان زمـانى

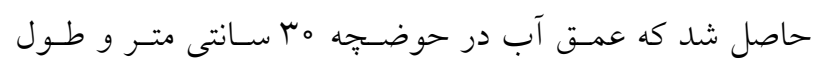
صفحات هدايت جريان ه/ بr سانتى متر و زاويه قرارگيـرى آنهـا نسبت به جريان ورودي مب درجه بـوده اسـت. اسـتفاده از ايسن شرايط مىتواند راندمان را بهميزان ش/r| درصد نسبت به حالتى كه نسبت به حالتى كه حوضجه فاقد تيغه بـوده و عمـق آب در

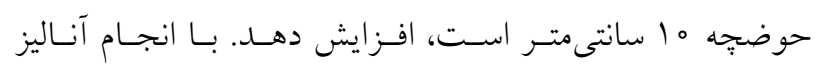
حساسيت نشان داده شد كه تغييرات عمق آب بيشترين تـأثير را بر تغييرات راندمان تلهاندازى حوضجه ترسيب دارد. بـهنيـر از عمق آب در حوضجه ترسيب، طول تيغه هدايت كننده جريسان و زاويه قرارگيرى تيغهها تقريباً تأثير يكسانى بر راندمان تلهاندازى حوضـجهه ترسـيب دارد و تركيـب ايسن دو عامـل و قرارگيـرى تيغهها با طول و تحت زاويه مناسب نسبت بـه جريـان ورودى، مىتواند راندمان حوضجهه را به مقدار قابل توجهى افزايش دهد.
استفاده مىشود، نسبت به زمـانى كـه حوضـجهه فاقـد صـفحات هدايت جريان است، افزايش مىيابد. بايد در نظر داشت تركيب هر دو عامل افزايش طول و افزايش زاويه هـزمــان نمسىتوانتـــ

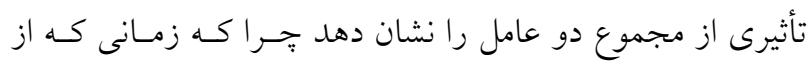

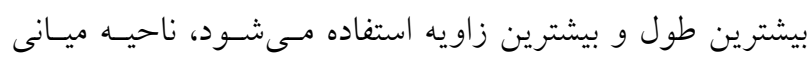
عبور جريان در حوضجه كاهش يافته و موجب افزايش سـرعت جريان و در نتيجـهـ كـاهش رسـوبكَذارى مسىشـود. بنـابراين شرايط بهينهاى از اين دو عامل بايد وجود داشته باشـــ تـا تـأثير مثبتى بر ميزان راندمان تله|ندازى حوضـهِه رسـوبَّيـر داشـته

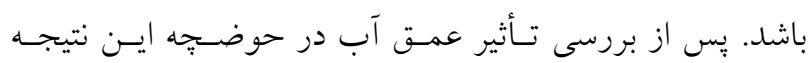

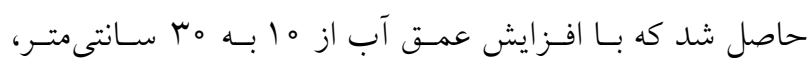

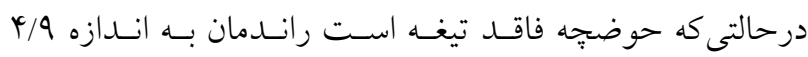
درصد افزايش مى يابد. در يزوهش حيـدرى و شـفاعىبجسـتان (1) نيز با افزايش عمق آب در حوضجههـاى رسـوبك كيـر بـا و

منابع مورد استفاده ا. حيدرى، م. م. و م. شفاعى بجستان .بهوا. بررسى آزمايشخاهى تأثير صفحات آرامكننده جريان بر بهبـود رانـدمان رسـوبـــارى

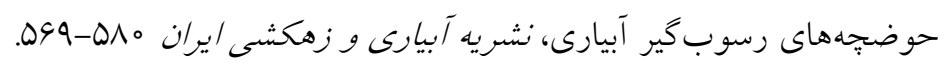

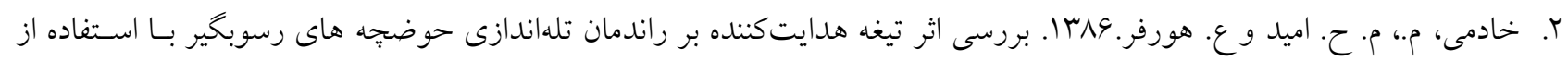

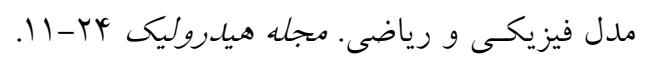

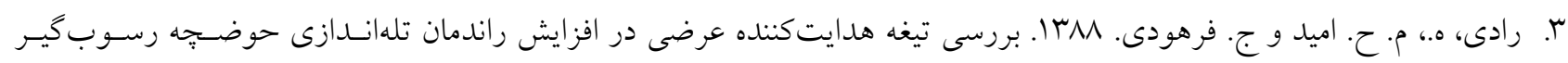

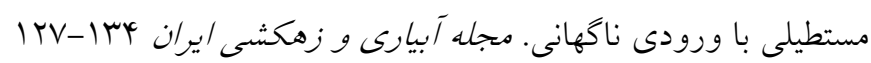

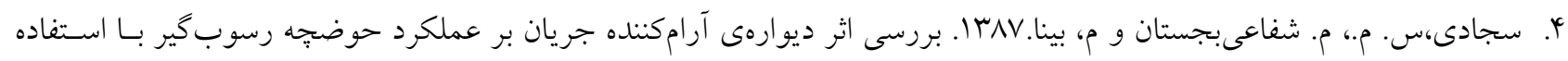

$$
\text { از مدل رياضى. سومين كنفرانس مديريت منابع آب ايران. دانشخاه تبريز. }
$$

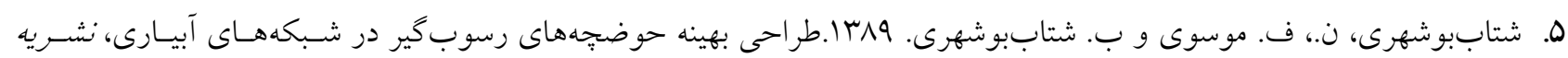

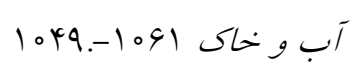

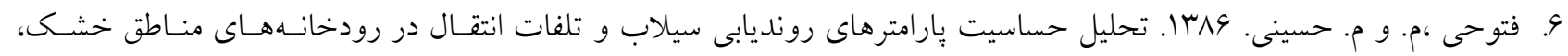

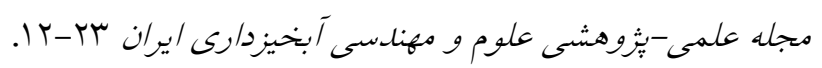

7. Ahmad, F. 2016. Comparative analysis of sediment removal efficiency parameters of settling basin. International Journal of Engineering and Advanced Technology 5: 136-140.

8. Atkinson, E. 1992. The Design of Sluiced Settling Basins-A Numerical Approach, Rep. OD 124, Overseas Development Unit, HR Wallingford, U.K.

9. Barkdoll, B. D., R.E ttema and A. J. Odgaard. 1999. Sediment control at lateral diversions: limits and enhancements to vane use. Journal of Hydraulic Engineering, ASCE 125: 862-870.

10. Camp, T. R. 1943. The effect of turbulence on retarding settling. In: Proceeding of the $2^{\text {nd }}$ Hydraulics Conference, 
University of Iowa, USA. PP: 307-317.

11. Camp, T. R. 1946. Sedimentation and the design of settling tanks. Trans. ASCE 111: 895-936.

12. Garde, R. J. and K. G. Ranga Raju. 1977. Mechanics of Sediment Transportation and Alluvial Stream Problems. Wiley Eastern Limited, New Delhi.

13. Goula, A. M., M. Kostoglou, T. D. Karapantsios and A. I. Zouboulis. 2007. A CFD methodology for the design of sedimentation tanks in potable water treatment case study: The influence of a feed flow control baffle. Chemical Engineering Journal 140: 110-121.

14. Heydari, M. M., M. Shafai Bajestan, H. A. Kashkuli and H. Sedghi. 2013. The effect angle of baffle on the performance of settling basin. Journal of World Applied Sciences 21(6): 829-837.

15. Imam, E. H., J. A. McCorquodale and J. K. Bewetra. 1983. Numerical modeling of sedimentation tanks. Journal of Hydraulic Engineering 12: 1740-1754.

16. Nakato. T. 1984. Model Investigation of Intake Shoaling and Pump-vibration Problems: Iowa Generation Council Bluffs unit 3 Circulation Water Intake (IIHR Report). No 283 Iowa Institute of Hydraulic Research, The University of Iowa, USA.

17. Rouse, H. 1949. Engineering Hydraulics. John Wiley, New York.

18. Ranga Raju, K. G., U. C. Kothyari, S. Srivastav and M. Saxen. 1999. Sediment removal efficiency of settling basin. Journal of Irrigation and Drainage Engineering 125(5): 308-314.

19. Shahrokhi, M, F. Rostami, M. A. Said, S. R. Sabagh Yazdi and S. Syafalni. 2012. The effect of number of baffles on the improvement efficiency of primary sedimentation tanks. Applied Mathematical Modeling 36: 3725-3735.

20. Shahrokhi, M., F. Rostami, M. A. Said and S. Syafalni. 2013. Numerical modeling of baffle location effects on the flow pattern of primary sedimention tanks. Applied Mathematical Modeling 37: 4486-4496.

21. Sumer, M. S. 1977. Settlement of solid particles in open- channel flow. Journal of Hydraulics 103: 1323-1337.

22. Singh, K., M. Pal, C. Ojha and V. Singh. 2008. Estimation of removal efficiency for settling basins using neural networks and support vector machines. Journal of Hydraulic Engineering 13: 146-155.

23. Wiegmann, H. and M. Neuhaus. 1951. Particle dispersion in isotropic turbulence under stokes drag and Basset force with gravitational settling. Journal of Fluid Mechanics 4: 122-133. 


\title{
A New Plan to Use Guide Fow Plates in Settling Basin for Increasing the Trap Efficiency
}

\author{
K. Esmaili ${ }^{*}$ S. Seifi and H. Salari ${ }^{1}$ \\ (Received: December 22-2016 ; Accepted: November 28-2017)
}

\begin{abstract}
Settling basins are one of the most essential structures for the separation of inflow sediments. This structure is established to enhance the water quality after the river-basins and water channels. Numerous studies have been conducted on the design of this structure and different methods have been provided to increase its efficiency. However, the use of simple settling basins with the minimum cost which can provide the ideal targets has been the focus of designers. In this study, the effect of flow-guiding plates and the angle between these and the inflow, and the impact of water depth in the basin on the trap efficiency of the settling basins were considered. For testing, 4 blades with specific length and angle were installed. This experiment was repeated for 3 different lengths and 3 angles. The results of the experiments showed that with the enhancement of the depth of water to 10 centimeters to 30 centimeters, while the basin had no flow-guiding plates, increased the trap efficiency of the basin by 4.9 percent. Also, by the use of flowguiding plates in the suitable and best length and angle (in this study, the suitable size of blades was 22.5 centimeters and the best position was by the angle of 30 degrees); with the maximum of the water depth of 30 centimeters, the trap efficiency was increased by 13.3 percent. The sensitivity analysis done showed that the depth of water had the most effect on the trap efficiency of the basin and the changes in the lengths and angles of the blades position had the similar effects of the basin trap efficiency.
\end{abstract}

Keywords: Settling basin, Guide flow plates, Water quality enhancement

1. Department of Water Engineering, College of Agriculture, Ferdowsi University, Mashhad, Iran.

*: Corresponding Author, Email: esmaili@um.ac.ir 